\title{
Rural Infrastructure and its Implication to Labor Market Participation in Jimma Zone, South-West Ethiopia
}

\author{
Minyahil Alemu \& Amsalu Dachito \\ Jimma University, Jimma, ETHIOPIA \\ Business and Economics College
}

Received: 9 August 2020 - Accepted: 27 November 2020 - Published Online: 17 December 2020

\begin{abstract}
Rural economy remain the back bone of Ethiopian economy absorbing tremendous labor share while how these labor market behave in rural economy of Ethiopia is yet uncovered. Besides the appreciated role of rural access to basic infrastructure with reference to rural labor supply decision, the topic is not bold in domestic literature. Considering this inadequate attention to the topic, we tried to examine the impact of rural infrastructure provision on individual labor supply, and assess the implication with each component of rural services to household participation decision in the labor market, using household survey from Jimma zone. Our multinomial logit regression indicated that rural services like education, health, credit, market information and access to all-weather-road are important considerations with regard to individual labor supply decision in farm and off-farm activities. It would be better to enhance rural access to efficient agricultural extension as well as other basic services towards empowering rural livelihood, and ensuring economic transformation at large.
\end{abstract}

Keywords: infrastructure, labor supply, market participation, multinomial logit.

\section{Introduction}

Needless to say, agriculture in Ethiopia is and continues to have a destiny defining contribution in the country's economy. Much has been said concerning the rural economy in Ethiopia about its nature, contribution as well as challenges in the area. Apparently, rural economy stays back bone of Ethiopian economy absorbing tremendous labor share while how these labor market behave in rural economy of Ethiopia is yet unknown. The government is determined to narrow the infrastructural black hole in the country in terms of accessibility as well as distribution, whereas its role in smoothing rural markets (where labor is one and the most) is not yet well studied. Having this overall objective in mind, this study tried to capture the link that might exist between infrastructural accessibility and labor market participation of rural households in Jimma zone, Oromia regional state.

The study is basically concerned with analyzing the rural infrastructure accessibility and its implication for labor market participation of smallholders across sections in Jimma zone. The following specific issues have been specifically targeted:

- Identifying the available physical as well as social infrastructures;

(C) Authors. Terms and conditions of Creative Commons Attribution 4.0 International (CC BY 4.0) apply. Correspondence: Amsalu Dachito, Jimma University, Business and Economics College, Jimma, ETHIOPIA. E-mail: dachinamo@gmail.com. 
- Identifying determinants of labor market participation decisions of household; and

- Estimating the impact of rural infrastructure on the rate of labor market participation in the study area.

\section{Methodology}

\subsection{Description of the study area}

This study is limited to Jimma Zone of Oromia regional state. Geographically, Jimma zone is located in South Western part of the country, Ethiopia. According to the official report from Jimma zone's administration office in $2016 / 17$, the zone is totally composed of twenty districts called Woreda. The number of population is estimated at around three million under 516,321 households.

Jimma Zone have an agro-ecological background of highlands (15\%), midlands (67\%) and lowlands (18\%) as documented by the United Nations Development Program country report for Ethiopia (UNDP, 2014). The zone is among major coffee growing areas in the country. The Zone reliably receives good rains, ranging from $1200-2800 \mathrm{~mm}$ per annum; this atmosphere is very comfortable to invest in the area of agro-industry based on natural resource well-endowed by nature, as well as product produced by active and strong community (UNDP, 2014). Below is the official geographic map of Jimma zone.

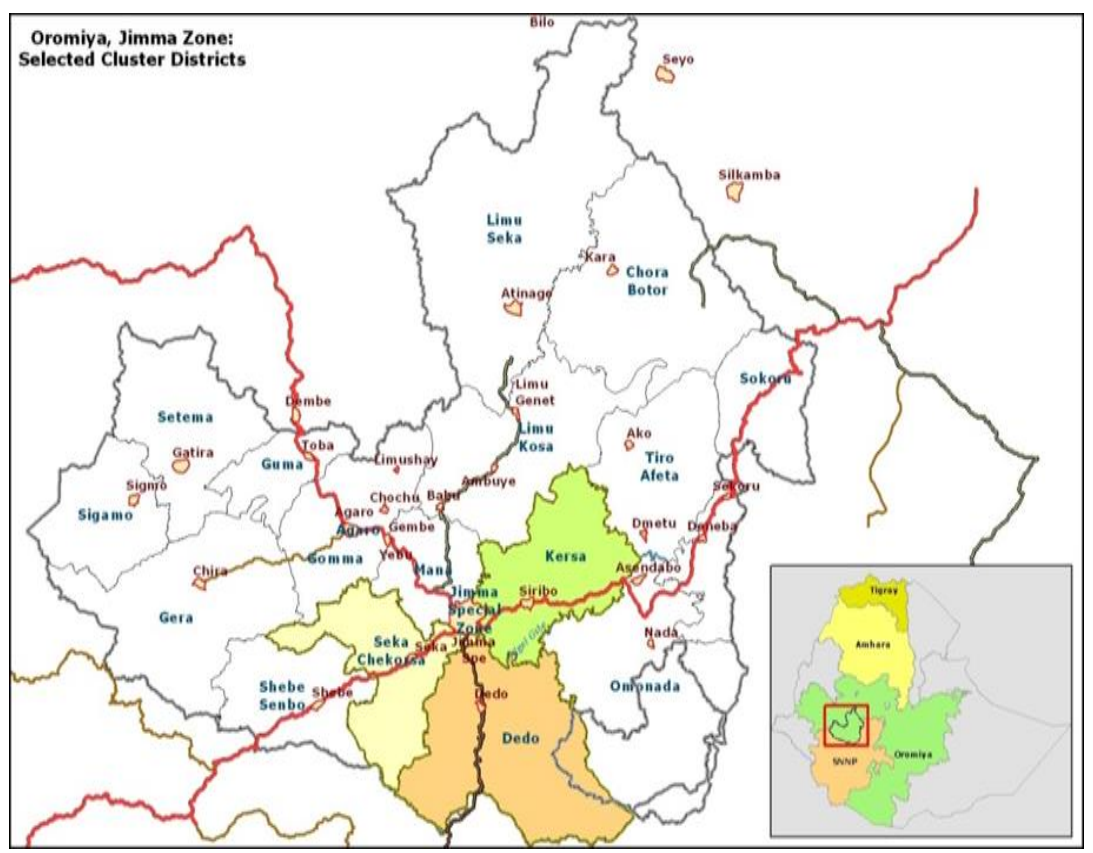

Figure 1. Geography of Jimma zone

\subsection{Type and source of data}

In its nature the data we used was cross-sectional. The survey has used both primary and secondary data set. While the primary data were obtained from the households via structured questions, secondary data were sourced from local trade and industry offices and investment offices. 


\subsection{Sampling methods and sample size determination}

For the purpose of the current survey we randomly took four (Limmu Kossa, Shebe Sombo, Gomma and Manna) out of twenty one districts in Jimma zone. Again proportional sample of kebele is arbitrarily selected from each woreda. At the end, households were proportionally randomly selected from each kebele, that were chosen from all four woreda listed above. The required size of sample has been determined following Noel et al. (2012):

$$
n \geq \frac{N}{1+(N-1)\left(\frac{2 d}{z}\right) 2}=390
$$

Where $N$ is population size; $n$ represents the sample; $(d=0.05)$ is chosen margin of error; $Z=1.96$ for 95 per cent confidence interval. Note that, the final draw of proportionate size each kebele was quite random.

\subsection{Multinomial logit model specification}

Labor market has an interesting and unique role in agricultural and off-farm sectors, within the wider input market in the rural economy. Timmer (1987) recognizes the agricultural labor should be commonly treated as a 'buffer' in economic development. When other sectors in the economy prosper, the agricultural sector tends to signal through releasing the work force from agriculture to other sector whereas at the time of difficulty, the sector tends to absorb more labor from other sectors. By doing so, the sector thus avoids any dramatic unemployment problems. Literature related to the institutional frameworks of rural labor markets is rare if not absent. Most studies examining the institutional setting of agricultural labor markets in the rural sector often tend to refer to developing countries while typically addressing the failure associated with the smooth flow of labor market performances and the consequent effect for the productivity and efficiency of the agricultural sector (Guancheng et al., 2012). The labor supply of the rural households is a categorical variable that can be divided into farm and off-farm activities while the two broad categories can further be split into self-employed and regular wage (salary) earners.

In order to estimate the relative share of the determinants incorporated in this study on the variable under consideration, four distinct participation choices are identified: (i) selfemployed in farm sector, (ii) regular wage earner in farm sector (iii) self-employed in off-farm sector, (iv) regular wage earner in off-farm sector. In the case of the off-farm sector, one or more than one of the household members may be employed in the sectors other than farming activities either in the rural area or nearby urban area. A household is considered as a participant in any of the two sectors, if there is/was at least one family member in the household who participated (currently participating) in any of the two activities or left the family member and moved to the urban area for paid work. Given the discrete nature of the dependent variable, the appropriate model to be adopted is multinomial logit model (Cragg, 1971; Wooldridge, 2015). Since the labor supply of the rural households is a categorical variable with discrete division, we employed the approach of multinomial logit model. That is the dependent variable, labor market participation, is a categorical variable having four possible values where the $\mathrm{i}^{\text {th }}$ household is participating in at least one of the activities defined above.

Multinomial logit given all the individual specific covariates $\left(\mathrm{x}_{\mathrm{i}}\right)$, the probability that the $i^{\text {th }}$ household choose the $\mathrm{j}^{\text {th }}$ activity $(\mathrm{j}=1,2, \ldots .4)$ such that since the households face a multiple choices, such as different activities to engage, where the order of those activities does not matter, unordered choice model is preferred which can be motivated by a random utility model. That is, for the $\mathrm{i}^{\text {th }}$ household faced with $J$ choices, the utility from choice $j$ can be given as (Wooldridge, 2013; Gujarati, 2004);

$$
U_{i j}=x_{i j} \theta+\varepsilon_{i j}
$$


Where $\mathrm{U}_{\mathrm{ij}}$ is unobserved (latent) utility of household $i$ from activity $j, X \mathrm{~s}$ are all the explanatory variables and $\theta$ stands for vector of parameters and $\varepsilon$ is the error term having a standard logistic distribution. If the consumer makes choice $j$ in particular, then we assume that $\mathrm{U}_{\mathrm{ij}}$ is the maximum among the $\mathrm{J}$ utilities assuming that a household under consideration is rational utility maximizer. That means the probability that choice $j$ is made among other choices if (Wooldridge, 2013; Cragg, 1971):

$$
\operatorname{pr}\left(U_{i j}>U_{i k}\right) \quad \text { for all } j \neq k
$$

Equation (2) states that the $i^{\text {th }}$ household can only be engaged in the activity $j$ if and only if the utility derived from this activity is greater than the utility from other activity $k$ keeping all else constant. The logit specification for the above equation can be given by;

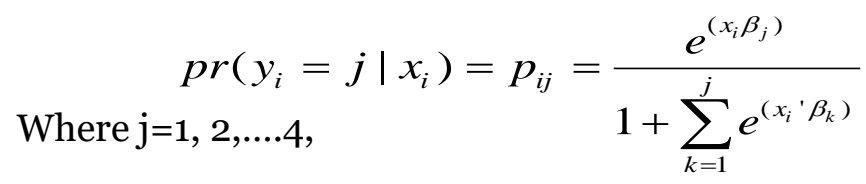

The sum of the $\mathrm{J}$ probabilities should equal to one. To avoid indeterminacy, we need only to estimate $\mathrm{J}-1$ parameters to obtain probabilities for $\mathrm{J}$ choice. If $\mathrm{J}$ is set to be 2 , then it becomes the typical binary logit model. We can compute the relative risk associated with the $\mathrm{J}$ activity (odds ratios) as:

$$
\frac{P_{i j}}{P_{i k}}=\exp \left(\beta_{j 1} x_{1}+\beta_{j 2} x_{2}+\ldots+\beta_{j k} x_{k}\right.
$$

Equation (4) is called odds ratio (the relative risk) associated with a choice of $j$ activity. Thus, the change in the odds ratio resulting from a unit change in the $k^{\text {th }}$ explanatory variable is equivalent to $\exp \left(\beta_{\mathrm{jk}}\right)$. From equation 4 , one can compute the log of the odds ratio by converting the above equation into logarithmic form.

$$
\ln \left(\frac{P_{i j}}{P_{i k}}\right)=\beta_{j 1} x_{1}+\beta_{j 2} x_{2}+\ldots+\beta_{j k} x_{k}=\mathrm{x}^{\prime} \beta_{\mathrm{j}}
$$

Equation (5) implies that the log of the odds ratio is linear function of the explanatory variables and the corresponding coefficients measure the change in the log of the odds ratio associated with a unit change in the explanatory variable under consideration. Thus, given multinomial logistic distribution assumption of the error term, utility for workers engaged in the employment category is the log odd ratio given by:

$$
\log i t(y=j)=\log \left(\frac{p(y=j)}{1-p(y=j)}\right)=\beta_{j 0}+\beta_{j 1} x_{1}+\beta_{j 2} x_{2}+\ldots .+\beta_{j k} x_{k}+\varepsilon \ldots \text { (6) }
$$

The above model (multinomial logit model) was estimated using maximum likelihood method. The slope coefficient captures the change in log odds of the household being in the job category $j$ as compared with the reference category given the change in one unit of independent variable keeping all else unchanged. The statistical significance of the parameter estimates can be checked using the usual $t$-test. 
3. Results and discussion

3.1 Descriptive statistics

3.1.1 Households' demographic characteristics

table below.

Demographic information identified for various response rates is presented in the

Table 1. Demographic variables characteristics

\begin{tabular}{llll}
\hline Marital status & Freq. & Percent & Cum. \\
\hline Married & 327 & 82.37 & 82.37 \\
Widowed & 12 & 3.02 & 85.39 \\
Divorced & 16 & 4.03 & 89.42 \\
Single & 42 & 10.58 & 100.00 \\
& & & \\
\hline $\begin{array}{l}\text { Education level } \\
\text { Illiterate }\end{array}$ & 140 & & \\
$<=6$ & 172 & 35.26 & 35.26 \\
$\quad \begin{array}{l}<=12 \\
\text { above 12 }\end{array}$ & 48 & 43.32 & 78.59 \\
& 37 & 12.09 & 90.68 \\
Sex of HH Head & 9.32 & 100.00 \\
$\begin{array}{l}\text { Male } \\
\text { Female }\end{array}$ & 305 & 76.83 & 76.83 \\
& 92 & 23.17 & 100.00 \\
\hline
\end{tabular}

Source: (Own Computation, 2019)

In terms of sex composition, the sector is dominated by male headed households where about 76.83 percent of the household heads are male while the remaining proportion is female headed. Being household head is more widely interpreted by different scholars and they attach it to economic freedom, and decision making power (Guancheng et al., 2019). In the context of Ethiopia's rural institution, female rarely become the household head, unless she is single, divorced or widowed. It is long lasting tradition in the country where farming activity is considered to be performed by male and female's role is considered as only supportive. In terms of marital status majority of the farm households (82.37 percent) are married which is followed by single (10.58 percent). The rest 4.03 and 3.02 per cent, respectively, are composed of divorced and widowed households.

\subsubsection{Labor supply decision by rural households}

Of the total response rate, majority (71.03\%) are engaged in farm activities (including labor sharing activities as well as sharecropping), followed by off farm sector which accounts 17.36 percent of the total sample households. The remaining 7.05 percent and 4.53 percent respectively have been engaging in the regularly paid and left outside of the labor market. Farm household labor supply diversification is believed to pursue additional income-generating activities at the farm-household level, including participation in livestock ranging, local non-farm activities, and off-farm activities whereas in the study area households are concentrated in the farm sector where the portion of farmers who are looking for alternative job outside their farm is relatively rare. Detail is provided hereunder: 


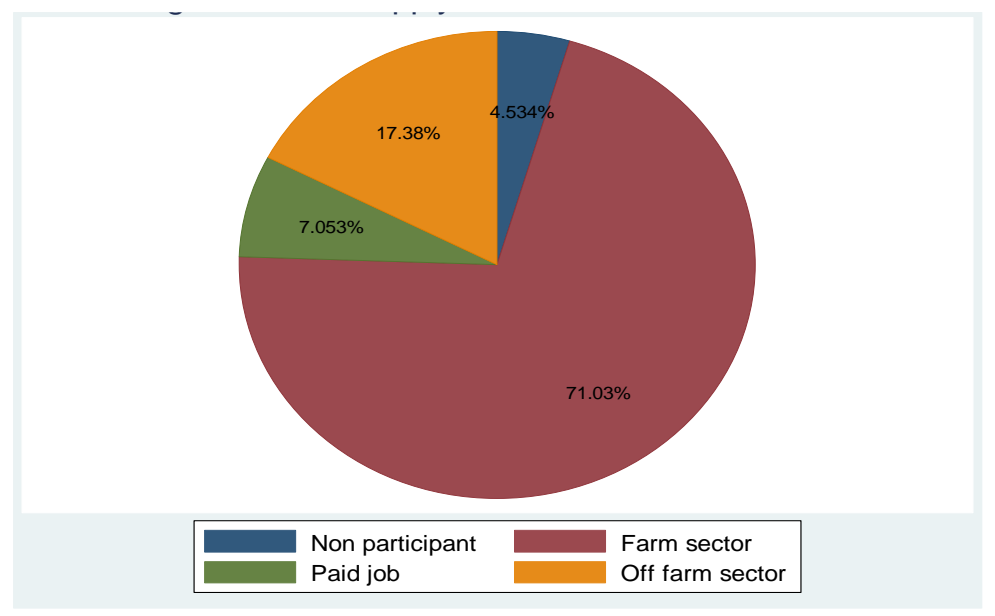

Source: (Own sketch, 2019)

Figure 2. Labor supply decision of the households

The most straight forward implication of labor supply diversification of farm households is that farmers look for generating a portfolio of income/wealth from sectors with dissimilar degrees of expected risk-returns combination, seasonality and liquidity so that they can be able to adjust their output mix accordingly to cop up with different seasonal hardships in rural area. According to Hoff (2000) farm diversification would facilitate the allocation of household scarce and productive assets among different income generating activities which may be in turn notable from village-level diversification, where households become more specialized in a given line of work over time, which in turn provide wider range of goods and services that would contribute to the economic development.

\subsubsection{Rural access to infrastructures}

It is worthwhile to mention that the two types of infrastructures (hard and soft) are like two sides of a coin that it is difficult to think of one without insuring the other. The survey result on the accessibility of both forms is given below.

Table 2. Infrastructural distribution

\begin{tabular}{lccr}
\hline \multicolumn{1}{c}{ Response } & Freq. & Percent & Cum. \\
\hline No access to road & 109 & 27.46 & 27.46 \\
Access to road & 288 & 72.54 & 100.00 \\
\hline No access to School & 39 & 9.82 & 9.82 \\
Access to school & 358 & 90.18 & 100 \\
\hline No access to credit & 31 & 7.81 & 7.81 \\
Access to credit & 366 & 92.19 & 100.00 \\
\hline No market information & 107 & 26.95 & 26.95 \\
Have market information & 290 & 73.05 & 100.00 \\
\hline
\end{tabular}

Source: (Own computation, 2019)

Evident from table 2 is reveals that, bout 27.46 percent of the total response rate have no access to all weather roads while the remaining 72.54 per cent do. In terms of access to schooling, around 10 percent of the farm households have no access to school while the remaining 90 per cent have been accessing it. Regarding access to formal credit facilities, around 8 percent of the household have no access to the service while looking actively for it. For aggregation purpose, households who have no demand to the service are categorized as if they have access to 
the service. Accordingly, about 92 percent of the households can be able to fulfill their financial constraints from the formal financial market (where most of them have access to microfinance institutions and majority of those who are treated here accessing the service were still no access to formal banking scheme.

Concerning market information accessibility which is proxied by the availability of mobile phone at least by one of the family member, irrespective of the availability of telecommunication network in the area, around 27 percent of the sampled households have no access to the market information while the remaining 73 per cent do access the same. In this regard, it is undeniable that information plays profound role in improving rural livelihood as farmers require updated information concerning different markets such as inputs and produce markets, as well as production and processing technologies that area available to their disposal. In general, improved access to information help community organization to strengthen local services provision and develop social capital.

Table 3. Tabulation of access to infrastructures and labor supply decision

\begin{tabular}{|c|c|c|c|c|c|}
\hline \multirow{2}{*}{$\begin{array}{c}\text { Infrastructure } \\
\text { 1. Access to Road }\end{array}$} & \multicolumn{5}{|c|}{ Labor Market Participation Decision } \\
\hline & Non participant & Farm & Paid job & Off farm & Total \\
\hline No & $\begin{array}{l}5 \\
27.78\end{array}$ & $\begin{array}{l}77 \\
27.30\end{array}$ & $\begin{array}{l}5 \\
17.86\end{array}$ & $\begin{array}{l}22 \\
31.88\end{array}$ & $\begin{array}{l}109 \\
27.46\end{array}$ \\
\hline Yes & $\begin{array}{l}13 \\
72.22\end{array}$ & $\begin{array}{l}205 \\
72.70\end{array}$ & $\begin{array}{l}23 \\
82.14\end{array}$ & $\begin{array}{l}47 \\
68.12\end{array}$ & $\begin{array}{l}288 \\
72.54\end{array}$ \\
\hline \multicolumn{6}{|l|}{ 2. Access to School } \\
\hline No & 2 & 27 & 4 & 6 & 39 \\
\hline & 11.11 & 9.57 & 14.29 & 8.70 & 9.82 \\
\hline Yes & & 255 & 24 & 63 & 358 \\
\hline & 88.89 & 90.43 & 85.71 & 91.30 & 90.18 \\
\hline \multicolumn{6}{|l|}{ 3. Access to Credit } \\
\hline No & $\bar{O}$ & 22 & 5 & 4 & 31 \\
\hline & 0.00 & 7.80 & 17.86 & 5.80 & 7.81 \\
\hline Yes & 18 & 260 & 23 & 65 & 366 \\
\hline & 100.00 & 92.20 & 82.14 & 94.20 & 92.19 \\
\hline \multicolumn{6}{|l|}{ 4. Access to Mkt inf. } \\
\hline No & 5 & 86 & 4 & 12 & 107 \\
\hline & 27.78 & 30.50 & 14.29 & 17.39 & 26.95 \\
\hline Yes & 13 & 196 & 24 & 57 & 290 \\
\hline & 72.22 & 69.50 & $85 \cdot 71$ & 82.61 & 73.05 \\
\hline
\end{tabular}

First row has frequencies and second row has column percentages

Source: (Own Computation, 2019)

Out of the total farm households who were outside of the labor market, 27.78 per cent had no access to all-weather road and the rest 72.22 percent have access to the same infrastructure. Out of the total farm households in the study area who have been engaging in the farm sector 72.7 percent have access to road whereas the rest 27.3 percent have no access to it. In addition, 32 percent and 18 percent of the sampled household from off farm sector and paid job respectively have no access to all-weather road.

Regarding access schooling, around 9.6 percent of households engaged in the farm sector didn't have access to schooling. On the other hand around 89 per cent from the non-labour force, 90 percent from farm sector, 86 percent from paid and 91 percent from off-farm sector have access to education. It indicates that individuals from farm sector are relatively more vulnerable 
in terms of being outside of schooling in particular and any infrastructure in general. It farther implies that there is uneven distribution of infrastructural facilities across different sectors in rural economy and might be the case that those who have enough access to those infrastructures were the one who were exposed to other alternative sectors and who could be able to look for jobs outside the farm sector. In a like passion, access to market information varies with labor supply decisions of the farm household in the study area as market information is concentrated in the offfarm and regularly paid job (about 83 percent and 86 percent of farm households in each sector respectively have access to market information). In contrast, majority of households who were outside the labor force (72 percent) didn't have access to market information which is followed by the farm sector (70 percent).

\subsubsection{Labor market participation decision of households}

Factor market fails for many reasons where some of them are demand side factors while others are supply side factors. These imperfections are striking when it comes to rural area. These factors differ with sectors. For instance, low level of education and skill are the main cause in farm sector and it is no more an impending factor in the paid job. The responses from the current survey are summarized in the table below.

Table 4. Impeding factors of alternative job in the study area

\begin{tabular}{l|lll}
\hline \multicolumn{1}{c|}{ Impeding factors } & Farm & Off-farm & Paidjob \\
\hline The level of education and skill & 218 & 15 & 2 \\
No info. about alternative job & 53 & 52 & - \\
Risky to leave current job and search for alternatives & 86 & 41 & 9 \\
Limited access to land and capital & - & 10 & 6 \\
Preference to stay in one's current residence & 98 & 25 & - \\
There is no alternative job opportunity & 186 & 62 & 20 \\
\hline
\end{tabular}

Source: Compiled from HH Survey Response (2019)

The demand and supply side factors holding the rural households from looking alternative jobs around their residence and nearby urban areas are discussed in this part. One of the factors that limited farmers from engaging in alternative jobs is the absence of alternative jobs in the rural area. In most of the rural area there are no alternative off-farm jobs as well as formal (paid) job. This implies that there is a demand side constraint in the rural area that most of alternative off- farm jobs are concentrated in the urban area so that people are obligated to move from rural to urban center for better job. From the economic theory perspective, farmers' labor supply decision is based on their objective of utility maximization so that they divide their labor time among different sectors (farm, off-farm and paid jobs) so that the expected marginal return from all the alternative sectors remain equal. Nevertheless, farmers are believed to be risk averse so that they allocate less time to risky sector and more time to less risky sectors (though farmer's version of risk definition may be different). Accordingly, significant portion of farm households in the study area who have been engaged in the farm sector prefer to stay in the sector that they fear taking any risk in searching alternative jobs rather than farming.

\subsection{Evidence from multinomial logit analysis}

Before we directly approach to the regression our logit specification, we have examined all of the validity and reliability conditions and none of them was suggested invalid. Our test statistics are presented herewith for convenience. 
Table 5. Diagnostic test results, Stata ver.14

\begin{tabular}{lllll}
\hline Test statistics & Null Hypothesis & Values & Prob. & Null hyp. \\
\hline Mean VIF & Multicollinearity & 1.04 & - & Rejected \\
Lawley chi2 & Same correlation matrix & 73.18 & 0.00 & Rejected \\
Hettest & Constant variance & 25.91 & 0.00 & Rejected \\
Breusch-Godfrey LM & No serial correlation & 0.001 & 0.97 & Accepted \\
Cook's D & Outlier & 0.0026 & - & Rejected \\
Link test & & & & \\
$\quad$ hat & No omitted variable & 0.31 & 0.77 & Accepted \\
$\quad$ hat-squared & & 0.14 & 0.51 & \\
D-Watson stat & & 2.01 & - & \\
\hline
\end{tabular}

Source: (Own Analysis, 2019)

This section presents the potential determinants of rural household labor supply decision with reference to Jimma zone. Table 6 below reports the results from our regression.

Table 6. Determinants of labor market participation decision (Multinomial logit model)

\begin{tabular}{|c|c|c|c|}
\hline Lmp & Coef. & Std.Err. & t- value \\
\hline Age & $-0.343^{* * *}$ & 0.116 & -2.95 \\
\hline Age squared & $0.004^{* * *}$ & 0.001 & 3.21 \\
\hline Sex of HH head & 0.844 & 0.608 & 1.39 \\
\hline Marital status & -0.030 & 0.281 & -0.11 \\
\hline Education & $1.314^{* * *}$ & 0.256 & 5.12 \\
\hline Family size & 0.260 & 0.210 & 1.24 \\
\hline Family labour & $-0.769^{* *}$ & 0.305 & -2.52 \\
\hline Access to road & 0.305 & 0.612 & 0.50 \\
\hline Dependency & & 0.019 & -1.25 \\
\hline Access to credit & $14.934^{* * *}$ & 0.436 & 34.27 \\
\hline Access to Ext. & 0.0212 & 0.613 & 0.03 \\
\hline Access to mkt in & 0.178 & 0.577 & 0.31 \\
\hline Remittance & $0.000^{* * *}$ & 0.000 & 3.88 \\
\hline land_sz & 0.068 & 0.130 & \\
\hline Age & 0.036 & 0.127 & 0.28 \\
\hline Age squared & 0.000 & 0.001 & -0.15 \\
\hline Sex of HH head & -0.273 & 0.593 & -0.46 \\
\hline Marital status & $0.319^{*}$ & 0.179 & 1.78 \\
\hline Education & $1.415^{* * *}$ & 0.207 & 6.83 \\
\hline Family size & -0.265 & 0.174 & -1.52 \\
\hline Family labour & $0.546^{*}$ & 0.310 & 1.76 \\
\hline Access to road & $1.496^{* *}$ & 0.604 & 2.48 \\
\hline Dependency & 0.020 & 0.016 & 1.25 \\
\hline Access to credit & -0.722 & 0.632 & -1.14 \\
\hline Access to Exten & 0.0962 & 0.353 & 0.272 \\
\hline Mkt info & 0.676 & 0.503 & 1.34 \\
\hline Remittance & 0.000 & 0.000 & -0.52 \\
\hline land_siz & $0.086^{*}$ & 0.151 & \\
\hline Age & 0.067 & 0.112 & 0.60 \\
\hline Age squared & -0.001 & 0.001 & -0.53 \\
\hline Sex of HH head & 0.461 & 0.479 & 0.96 \\
\hline Marital status & 0.127 & 0.208 & 0.61 \\
\hline Education & $2.481^{* * *}$ & 0.254 & 9.77 \\
\hline Family size & -0.175 & 0.189 & -0.92 \\
\hline Family labour & 0.234 & 0.273 & 0.86 \\
\hline Access to road & 0.313 & 0.477 & 0.66 \\
\hline
\end{tabular}


M. Alemu \& A. Dachito - Rural Infrastructure and its Implication to Labor Market ...

\begin{tabular}{lccc} 
Dependency & 0.012 & 0.016 & 0.78 \\
Access to credit & 0.155 & 0.672 & 0.23 \\
Access to Exten & 0.112 & 0.613 & 0.03 \\
Access to mkt info & $0.915^{*}$ & 0.473 & \\
Remittance & $-0.0620^{*}$ & 0.124 & -0.26 \\
Constant & $-12.164^{* * *}$ & 3.248 & -3.75 \\
Mean dependent var & 1.373 & SD dependent var & \\
Pseudo r-squared & 0.316 & Number of obs \\
Chi-square & 1890.588 & Prob > chi2 & \\
Akaike crit. (AIC) & 552.885 & Bayesian crit. (BIC) \\
\hline
\end{tabular}

\footnotetext{
*** Significance at 1 per cent;

** significance at 5 per cent;

* Significance at 10 per cent

Source: Own estimation (2019)
}

The overall significance of the model is assured given the conventional Wald ch2 test and the null hypothesis that all coefficients are jointly zero is strongly rejected in favor of alternative at one percent significance $(p=0.00)$. The dependent variable (labor force participation) is a categorical variable having 4 values where the four values are types of the sectors that rural households could possibly engage (non-participant, farm sector, off-farm sector and regularly paid job) where the first is taken to be the base category so that the participation of the households in the three of the remaining sectors are analyzed by comparing with the base categories.

Households in the study area are subdivided into four groups (those individuals currently not working, individuals engaged in farm activities, and off-farm sector as well as individuals who engaged regularly at paid job) and hence, the factors determining labor market participation in each group has been estimated using multinomial logistic regression model and the result is reported in the above table (Table 6).

\subsubsection{Impact of rural infrastructure on household labor supply decision}

(a) Labor supply decision in farm sector

In this study we assumed that farmers who are engaging at own farm plot as well as who have been engaged in the labor sharing activities are put under this category. Therefore, those under this category are basically engaged in self-employment in his/her own farm and for aggregation purpose, those individuals who are working on other's farm in terms of sharecropping are also treated as farmer who are supplying their labor in farm sector. Based on the estimates reported above, access to different types of infrastructural facilities such as road, credit and market information have positive effect on the likelihood of farmers joining farm sector, though access to credit facilities is the only statistically significant variable. This demonstrates that in order to boost the likelihood of farmers to join the sector, financial institution have tremendous influence in smoothing financial constraints facing the farm household. This relation has been highlighted in previous works like, Fall and Magnac (2015), and Pollard and Heffernan (1983). More importantly, credit arrangement for investments is vital to encourage rural entrepreneurs make investment decision so as to create economic opportunities, and purchase agricultural inputs and working capital. Suggestive of the role of credit in agriculture, the global food price crisis has moved agricultural finance on top of the Africa and international development agenda. According to Goodwin and Holt (2002) access to financial market irrespective of the type of farm households engaged in the sector is a key so as to unleash and utilize the continent's potential in the sector as well as ensuring food self-sufficiency. 
Age of household head has negative contribution to the likelihood of households' engagement in farm sector which is happen to be significant at one percent level. On the other hand, age square has a positive contribution on the sector. The possible explanation for this is older household heads are relatively intensively engaging in the farm sector and those who are relatively young are those engaged in off-farm activities as well as in regular full time work. Aging labor forces in agricultural sector is the trend in most of the countries in the world (Guancheng et al., 2015). This has its own pros and cons. On one hand aging farmer having more experience and accumulated knowledge regarding the farming activities, their soil nature and related matching of the crop. On the other hand, farming demands physical strength throughout the farming process and those who are middle aged are strong and relatively productive in the sector. It is also argued in terms of the farmer's acceptance of the new technology, old people are relatively conservative and reluctant in accepting new technology compared to the young.

Education level of the household head and family labor are also significant considerations with likelihood of labor supply in the farm sector where the former is significant and positive at one percent level, while the latter has negative and significant at five percent level. The positive impact of education is intuitive as the household head who is relatively young is the one with more years of schooling and ready to supply his or her labor in the sector as compared to the older one. Concerning family labor, it has negative sign implying that one with larger family size tends to get out of the sector.

(b) Labor supply decision in off-farm sector

Rural households face diverse challenges in copping up with rural poverty and living condition. The problem is severing when it comes to Africa (UNDP, 2014). Cognizant of this fact, households in these countries espouse different livelihood strategies. This strategy holds diversifying the income base of household and avoiding sole dependency in the rural agriculture sector (Stefan \& Barret, 2011; Sumner, 1987). One potential means would be to enhance participation in off-farm sector which could only be realized if farmers have access to different assets that paves ways to off-farm sector. In our model above, different household specific variables are estimated as potential determinants in affecting household's decision to join this sector while four variables are identified as statistically significant in determining smallholders' engagement in the off-farm sector where access to road is one. Access to road is positive and significant in increasing the likelihood of farm households' decision to participate in this sector.

(c) Labor supply decision in formal (paid) job in farm and off-farm sectors

Household heads who are engaged in rural regular paid job (on hired contractual or permanent basis) are relatively non-existent in the area. Among the modeled variables under this group of employment, only four are significant in determining small farm households' engagement in this sector. These are level of education of the head, market information, remittance and land size. Accordingly farmers with higher education tend to participate outside of their own farm looking for regularly paid work as compared to illiterate farmers. This is not surprising as education intensify the chance of a household to look for alternative work (Juvančič \& Erjavec, 2005; Kimhi, 1994). On the other hand, land size is one of the pushing factors as it has negative and significant impact. Households with large farm size tend to participate in the farm sector as well as in the off-farm sector and less likely to participate in the paid job.

\section{Conclusion and policy directions}

Rural households in the study area are concentrated in the farm sector while rarely participating in the off-farm and regularly paid sectors. Among others absence of alternative jobs outside the farm sector in the study area is the most hindering factor that restricts farmers to limit themselves in the farm sector. Farm households' risk aversion strategy in terms of diversifying 
their income base from farm sector is highly limited in the study area as farmers have limited access to the alternative job in off-farm as well as in the regular and formal paid sectors.

More than one-third of the total response rate indicated the lack of access to rural-allweather road from the settlement area. Besides, education, information, health and other services are not sufficiently provided. However, the provision of credit service was suggested fair. Based on the inferential analysis, accesses to different infrastructural facilities (such as road, credit service and information) contribute significantly for households' decision to supply labor in the farm sector. Level of education on the other hand increases the likelihood of labor supply in the farm sector where as family size acts negatively to the decision of households in engaging in the sector.

Accesses to road, the level of education, family labor and marital status of the household head were important with reference to off-farm labor supply decision. Except family labor, other three variables contribute positively to the labor supply decision of the household in the off-farm sector. One implication from this finding is that, enriching rural area in terms of education and training would pave the way to off-farm sectors and critical for income diversification of farm household in the study area. On the other hand, households with large family labor (large family size where most of them are participating in the labor supply) acts as pushing factor in the sector implying that households with large family labor prefer to stay outside of the labor force or search works in the paid job (as it is positive in the two cases and negative in the remaining two cases) rather than off-farm sector which implicitly show that family planning could contribute positively to the households' labor supply decision in the off- farm sector.

As labor service is not separable from the individual, there are factors preventing individuals from looking for alternative jobs. Rural people prefer not to migrate for institutional and social reasons as they are reluctant of losing long term established relations with their neighbors. Therefore, providing alternative jobs in off-farm sector in the rural area has paramount importance rather than expecting rural people to migrate for the search of better job. Besides, the absence of alternative and better job in their surrounding is the reason why rural households limit themselves in a single job while some think that it is relatively risky to shift from the job that they are currently familiar with and looking for alternative job. Therefore, it would be better for the government to create conducive environment in rural area which should be accompanied with awareness creation.

Remittance and land size of the rural households negatively affect rural households' participation in the paid job. Households who had access to external financing from extended families were not looking for alternative jobs outside their own farm. Besides, owning relatively large land size hinders rural households from looking for alternative jobs. Given the positive and significant effect of different infrastructural supply (such as access to road and information facilities) it is advisable if the government pays attention for enriching rural areas as a means of widening the alternative jobs available for rural households in the study area. Besides, granting land ownership right to the households in the study area boosts households' labor supply decision in the farm sector as well as attracts others from other alternative sectors towards the farm sector so that the local as well as regional governments need to work towards improving farmers' security related with access to farm land.

\section{Acknowledgements}

This research did not receive any specific grant from funding agencies in the public commercial, or not-for-profit sectors.

The authors declare no competing interests. 


\section{References}

Corsi A., \& Findeis, J. (2000). True state dependence and heterogeneity in off-farm labour participation. European Review of Agricultural Economics, 27(2), 127-151.

Cragg, J. G. (1971). Some statistical models for limited dependent variables with application to the demand for durable goods. Econometrica, 829-844.

DeSilva, S., Evenson, R. E., \& Kimhi, A. (2006). Labor supervision and institutional conditions: Evidence from Bicol rice farms. AJAE, 88(4), 851-865.

Fall, M., \& Magnac, T. (2004). How valuable is on-farm work to farmers? American Journal of Agricultural Economics, 86(1).

Goodwin, B., \& Holt, M. (2002). Parametric and semi parametric modeling of the off- farm labour supply of agrarian households in transition Bulgaria. American Journal of Agricultural Economics, 84(1).

Guancheng G., Qiyu, W., \& Jingjuan, Z. (2015). The impact of aging agricultural labour population on farmland output: From the perspective of farmer preferences. Mathematical Problems in Engineering, Volume 2015.

Gujarati (2004). Basic econometrics, $4^{\text {th }}$ Ed. New Delhi: Mc-Graw-Hill Publishing Company Limited.

Hoff, K. (2000). Beyond Rosenstein-Rodan: The modern theory of underdevelopment traps. World Bank Economic Conference.

Juvančič, L., \& Erjavec, E. (2005). Intertemporal analysis of employment decisions on agricultural holdings in Slovenia. Agricultural Economics, 33(2), 153-161.

Kimhi, A. (1994). Participation of farm owners in farm and off-farm work including the option of full-time off-farm work. Journal of Agricultural Economics, 45(2).

Stephen, E. C., \& Barrett, C. B. (2011). Incomplete credit markets and commodity marketing behavior. Journal of Agricultural Economics, 62(1).

Sumner, D. (1982). The off-farm labor supply of farmers. American Journal of Agricultural Economics, 64(3), 499-509.

Timmer, C. (1987). Farmers and markets: The political economy of new paradigms. American Journal of Agricultural Economics, 79(2).

United Nations Development Program (2014). Country Report Annual. Ethiopia 2014.

Wooldridge, J. (2015). Introductory econometrics: A modern approach, $5^{\text {th }}$ Ed. USA: Michigan State University. 
M. Alemu \& A. Dachito - Rural Infrastructure and its Implication to Labor Market ...

C O A $\mathrm{s}$ 